\title{
Increased accuracy in computed tomography coronary angiography; a new body surface area adapted protocol
}

\author{
E. E. van der Wall • J. E. van Velzen • F. R. de Graaf • M. M. Boogers • \\ J. D. Schuijf · J. J. Bax
}

Received: 29 March 2010/Accepted: 2 April 2010/Published online: 16 April 2010

(C) The Author(s) 2010. This article is published with open access at Springerlink.com

Amongst the advanced cardiac imaging modalities, multi detector computed tomography coronary angiography (CTCA) has emerged as a reliable noninvasive method for the assessment of coronary anatomy, coronary artery disease, and cardiac function [1-16]. Multiple studies involving over several thousands of patients have established that CTCA is highly accurate for delineation of the presence and severity of coronary atherosclerosis [9, 17-29]. CTCA may also reveal the total plaque burden, i.e., both calcified and non-calcified components, for individual patients with coronary atherosclerosis [30-39].

The advent of prospectively gated acquisition techniques for 64-slice CTCA has allowed a significant reduction in dose exposure [40-43]. Consequently, a combined approach of CTCA and myocardial perfusion imaging with CTCA angiography might potentially become feasible at a total radiation dose of much less than $10 \mathrm{mSv}$, particularly for the assessment of patients with established coronary artery disease, who are likely to have diffuse calcification [44-52]. In routine CTCA acquisitions, there might be a

Editorial comment on to the article of Pazhenkottil et al. (doi: 10.1007/s10554-010-9594-3).

E. E. van der Wall $(\varangle) \cdot$ J. E. van Velzen .

F. R. de Graaf · M. M. Boogers · J. D. Schuijf · J. J. Bax

Leiden University Medical Center, Leiden,

The Netherlands

e-mail: E.E.van_der_Wall@lumc.nl considerable signal density drop at the posterobasal wall resembling perfusion defects possibly being attributed to beam hardening artifacts [53] Beam hardening artifacts may be a common finding at CTCA of asymptomatic patients affecting predominantly the posterobasal wall, reducing the accuracy of CTCA. Also coronary vessel attenuation may affect the accuracy of CTCA as for an accurate detection of coronary plaque an appropriate amount of contrast material is needed. Coronary blooming artifacts caused by too large contract material amounts may hamper the detection of coronary plaque. The attenuation of coronary vessels is influenced by the individual patient's weight and height which are expressed by body mass index and body surface area (BSA) Attenuation of coronary vessels in CTCA is closely related to several factors including both patient specific characteristics such as body mass, blood volume and cardiac output and protocol-related parameters such as concentration and injection rate of the administered contrast material.

In patients with increased body mass CTCA image quality is degraded by an unfavorable shift in the signal-to-noise ratio due to increase in noise and loss of attenuation. Introduction of scan protocols with body mass index-adapted tube current and voltage have allowed handling the adverse effects of body mass on image noise. Therefore, BSA would be the most promising parameter to be used for contrast protocol adjustment. An ideal protocol should integrate both body mass index adaptation of tube 
parameters (noise minimization) and contrast material adjustment according to BSA (signal optimization). This may help differentiating coronary plaque from surrounding tissue and avoid blooming artifacts caused by intracoronary contrast material concentration. In patients with a large total blood volume, contrast material dilution decreases coronary attenuation in CTCA. In addition, increased blood volume is well paralleled by BSA.

In the current issue of the International Journal of Cardiovascular Imaging, Pazhenkottil et al. [54], using low-dose CTCA with prospective ECG-triggering, evaluated a BSA-adapted contrast material protocol to compensate for dilution effects in 80 patients with a BSA-adapted contrast material bolus ranging $40-105 \mathrm{ml}$ and injection rate ranging $3.5-5.0 \mathrm{ml} / \mathrm{s}$ for a BSA of $<1.70 \mathrm{~m}^{2}$ to $\geq 2.50 \mathrm{~m}^{2}$. A total of 80 controls matched for BSA who had previously undergone routine CTCA with a fixed contrast material protocol of $80 \mathrm{ml}$ at $5 \mathrm{ml} / \mathrm{s}$ served as reference group. The average vessel attenuation from both the proximal right coronary artery and the left main coronary artery was assessed. Correlation of BSA with vessel attenuation was assessed in both groups. Interestingly, the authors found that BSA-matching was successful in all patients (BSA-adapted group $1.98 \pm 0.15 \mathrm{~m}^{2}$ versus the reference group $1.98 \pm 0.17 \mathrm{~m}^{2}$ ). Mean contrast material bolus was significantly smaller in the BSAadapted versus the reference group (mean $70 \mathrm{ml}$ vs. mean $80 \mathrm{ml}$ ). There was no correlation in the BSAadapted group, while coronary attenuation was significantly inversely related to BSA in the reference group. It was concluded that a BSA-adapted contrast material protocol successfully results in a comparable coronary contrast enhancement independent of individual BSA. This was achieved despite a significant reduction in the overall contrast material amount. The findings of the present study therefore clearly show that the BSAadapted contrast material administration protocol is feasible and successful as the inverse correlation between BSA and coronary attenuation found in the control group could be abolished. As a result, range and standard deviation of coronary attenuation were smaller in the BSA-adapted group compared to the control group, indicating a well-balanced consistent contrast enhancement throughout a large range of BSA. Furthermore, by using the BSA-adapted protocol a significantly lower average amount of contrast medium was injected, which may help preventing contrast induced nephropathy and its consequences.

Previous studies [55-58] from the same group directed by Kaufmann had already shown that the use of the proposed body mass index-adapted scanning parameters results in similar image noise regardless of body mass index. Tatsugami et al. [55] initially showed that an increased bolus dilution due to larger blood volume may account for the decrease in contrast-to-noise ratio and vessel attenuation in patients with higher body mass index, but in this study the contrast bolus was not adapted to body mass index. Herzog et al. [56] showed that, after successfully overcoming the impact of body mass index on image noise by adapting tube parameters, the contrast to noise ratio mainly depends on coronary vessel contrast. The latter reflects the dilution of the contrast material by blood volume and cardiac output, which are both correlated to BSA. Therefore, BSA-adapted contrast administration may help to compensate for this effect. Husman et al. [57, 58] recently reported that a BMI-adapted contrast material protocol results in adequate coronary vessel attenuation independent of individual body mass index despite a significant reduction in overall amount of contrast material used.

To summarize, the current study validly extends previous findings that the proposed BSA-adapted contrast material protocol in patients undergoing lowdose CTCA results in adequate coronary vessel attenuation independent of individual BSA.

Open Access This article is distributed under the terms of the Creative Commons Attribution Noncommercial License which permits any noncommercial use, distribution, and reproduction in any medium, provided the original author(s) and source are credited.

\section{References}

1. van Werkhoven JM, Schuijf JD, Jukema JW et al (2008) Anatomic correlates of a normal perfusion scan using 64slice computed tomographic coronary angiography. Am J Cardiol 101:40-45

2. Schuijf JD, Bax JJ, van der Wall EE (2007) Anatomical and functional imaging techniques: basically similar or fundamentally different? Neth Heart J 15:43-44

3. Scholte AJ, Bax JJ, Wackers FJ (2006) Screening of asymptomatic patients with type 2 diabetes mellitus for silent coronary artery disease: combined use of stress myocardial perfusion imaging and coronary calcium scoring. J Nucl Cardiol 13:11-18 
4. Wijpkema JS, Dorgelo J, Willems TP et al (2007) Discordance between anatomical and functional coronary stenosis severity. Neth Heart J 15:5-11

5. Molhoek SG, Bax JJ, Bleeker GB et al (2004) Comparison of response to cardiac resynchronization therapy in patients with sinus rhythm versus chronic atrial fibrillation. Am J Cardiol 94:1506-1509

6. Thygesen K, Alpert JS, White HD (2007) Universal definition of myocardial infarction; joint ESC/ACCF/AHA/ WHF task force for the redefinition of myocardial infarction. Eur Heart J 28:2525-2538

7. van Lennep JE, Westerveld HT, van Lennep HW, Zwinderman AH, Erkelens DW, van der Wall EE (2000) Apolipoprotein concentrations during treatment and recurrent coronary artery disease events. Arterioscler Thromb Vasc Biol 20:2408-2413

8. Chamuleau SA, Vrijsen KR, Rokosh DG, Tang XL, Piek JJ, Bolli R (2009) Cell therapy for ischaemic heart disease: focus on the role of resident cardiac stem cells. Neth Heart J 17:199-207

9. de Leeuw JG, Wardeh A, Sramek A, van der Wall EE (2007) Pseudo-aortic dissection after primary PCI. Neth Heart J 15:265-266

10. Braun S, van der Wall EE, Emanuelsson S, Kobrin I (1996) Effects of a new calcium antagonist, mibefradil (Ro 405967), on silent ischemia in patients with stable chronic angina pectoris: a multicenter placebo-controlled study. The mibefradil international study group. J Am Coll Cardiol 27:317-322

11. Portegies MC, Schmitt R, Kraaij CJ et al (1991) Lack of negative inotropic effects of the new calcium antagonist Ro 40-5967 in patients with stable angina pectoris. J Cardiovasc Pharmacol 18:746-751

12. ten Kate GJ, Wuestink AC, de Feyter PJ (2008) Coronary artery anomalies detected by MSCT-angiography in the adult. Neth Heart J 16:369-375

13. Schuijf JD, Jukema JW, van der Wall EE, Bax JJ (2007) Multi-slice computed tomography in the evaluation of patients with acute chest pain. Acute Card Care 9:214-221

14. Groen JM, Greuter MJ, Vliegenthart R et al (2008) Calcium scoring using 64-slice MDCT, dual source CT and EBT: a comparative phantom study. Int $\mathrm{J}$ Cardiovasc Imaging 24:547-556

15. Bavelaar-Croon CD, Pauwels EK, van der Wall EE (2001) Gated single-photon emission computed tomographic myocardial imaging: a new tool in clinical cardiology. Am Heart J 141:383-390

16. van der Wall EE, Heidendal GA, den Hollander W, Westera G, Roos JP (1980) I-123 labeled hexadecenoic acid in comparison with thallium-201 for myocardial imaging in coronary heart disease. A preliminary study. Eur J Nucl Med 5:401-405

17. Bax JJ, Lamb H, Dibbets P et al (2000) Comparison of gated single-photon emission computed tomography with magnetic resonance imaging for evaluation of left ventricular function in ischemic cardiomyopathy. Am J Cardiol 86:1299-1305

18. Chamuleau SA, van Eck-Smit BL, Meuwissen $M$ et al (2007) Long-term prognostic value of CFVR and FFR versus perfusion scintigraphy in patients with multivessel disease. Neth Heart J 15:369-374
19. Bavelaar-Croon CD, Kayser HW, van der Wall EE et al (2000) Left ventricular function: correlation of quantitative gated SPECT and MR imaging over a wide range of values. Radiology 217:572-575

20. van der Wall EE, den Hollander W, Heidendal GA, Westera G, Majid PA, Roos JP (1981) Dynamic myocardial scintigraphy with 123I-labeled free fatty acids in patients with myocardial infarction. Eur J Nucl Med 6:383-389

21. van der Wall EE, van Dijkman PR, de Roos A et al (1990) Diagnostic significance of gadolinium-DTPA (diethylenetriamine penta-acetic acid) enhanced magnetic resonance imaging in thrombolytic treatment for acute myocardial infarction: its potential in assessing reperfusion. Br Heart $\mathbf{J}$ 63:12-17

22. van Dijkman PR, van der Wall EE, de Roos A et al (1991) Acute, subacute, and chronic myocardial infarction: quantitative analysis of gadolinium-enhanced MR images. Radiology 180:147-151

23. de Roos A, Matheijssen NA, Doornbos J, van Dijkman PR, van Voorthuisen AE, van der Wall EE (1990) Myocardial infarct size after reperfusion therapy: assessment with GdDTPA-enhanced MR imaging. Radiology 176:517-521

24. Pluim BM, Lamb HJ, Kayser HW et al (1998) Functional and metabolic evaluation of the athlete's heart by magnetic resonance imaging and dobutamine stress magnetic resonance spectroscopy. Circulation 97:666-672

25. van Rugge FP, Boreel JJ, van der Wall EE et al (1991) Cardiac first-pass and myocardial perfusion in normal subjects assessed by sub-second Gd-DTPA enhanced MR imaging. J Comput Assist Tomogr 15:959-965

26. van der Geest RJ, de Roos A, van der Wall EE, Reiber JH (1997) Quantitative analysis of cardiovascular MR images. Int J Card Imaging 13:247-258

27. van der Geest RJ, Niezen RA, van der Wall EE, de Roos A, Reiber JH (1998) Automated measurement of volume flow in the ascending aorta using MR velocity maps: evaluation of inter- and intraobserver variability in healthy volunteers. J Comput Assist Tomogr 22:904-911

28. van der Wall EE, Vliegen HW, de Roos A, Bruschke AV (1995) Magnetic resonance imaging in coronary artery disease. Circulation 92:2723-2739

29. Bleeker GB, Bax JJ, Fung JW et al (2006) Clinical versus echocardiographic parameters to assess response to cardiac resynchronization therapy. Am J Cardiol 97:260-263

30. Bleeker GB, Holman ER, Steendijk P et al (2006) Cardiac resynchronization therapy in patients with a narrow QRS complex. J Am Coll Cardiol 48:2243-2250

31. Ypenburg C, van der Wall EE, Schalij MJ, Bax JJ (2008) Imaging in cardiac resynchronisation therapy. Neth Heart $\mathbf{J}$ 16:S36-S40

32. Ypenburg C, Roes SD, Bleeker GB et al (2007) Effect of total scar burden on contrast-enhanced magnetic resonance imaging on response to cardiac resynchronization therapy. Am J Cardiol 99:657-660

33. Ypenburg C, Schalij MJ, Bleeker GB et al (2007) Impact of viability and scar tissue on response to cardiac resynchronization therapy in ischaemic heart failure patients. Eur Heart J 28:33-41

34. Vliegen HW, Doornbos J, de Roos A, Jukema JW, Bekedam MA, van der Wall EE (1997) Value of fast gradient echo magnetic resonance angiography as an adjunct to 
coronary arteriography in detecting and confirming the course of clinically significant coronary artery anomalies. Am J Cardiol 79:773-776

35. Hoogendoorn LI, Pattynama PM, Buis B, van der Geest RJ, van der Wall EE, de Roos A (1995) Noninvasive evaluation of aortocoronary bypass grafts with magnetic resonance flow mapping. Am J Cardiol 75:845-848

36. Holman ER, Buller VG, de Roos A et al (1997) Detection and quantification of dysfunctional myocardium by magnetic resonance imaging. A new three-dimensional method for quantitative wall-thickening analysis. Circulation 95: 924-931

37. Bakx AL, van der Wall EE, Braun S, Emanuelsson H, Bruschke AV, Kobrin I (1995) Effects of the new calcium antagonist mibefradil (Ro 40-5967) on exercise duration in patients with chronic stable angina pectoris: a multicenter, placebo-controlled study. Ro 40-5967 International Study Group. Am Heart J 130:748-757

38. Schuijf JD, Pundziute G, Jukema JW et al (2006) Diagnostic accuracy of 64-slice multislice computed tomography in the noninvasive evaluation of significant coronary artery disease. Am J Cardiol 98:145-148

39. Jongbloed MR, Lamb HJ, Bax JJ et al (2005) Noninvasive visualization of the cardiac venous system using multislice computed tomography. J Am Coll Cardiol 45:749-753

40. Schuijf JD, Wijns W, Jukema JW et al (2006) Relationship between noninvasive coronary angiography with multislice computed tomography and myocardial perfusion imaging. J Am Coll Cardiol 48:2508-2514

41. Pundziute G, Schuijf JD, Jukema JW et al (2007) Prognostic value of multislice computed tomography coronary angiography in patients with known or suspected coronary artery disease. J Am Coll Cardiol 49:62-70

42. Henneman MM, Schuijf JD, Pundziute G et al (2008) Noninvasive evaluation with multislice computed tomography in suspected acute coronary syndrome: plaque morphology on multislice computed tomography versus coronary calcium score. J Am Coll Cardiol 52:216-222

43. de Nooijer R, Verkleij CJ, von der Thüsen JH et al (2006) Lesional overexpression of matrix metalloproteinase-9 promotes intraplaque hemorrhage in advanced lesions but not at earlier stages of atherogenesis. Arterioscler Thromb Vasc Biol 26:340-346

44. van der Laarse A, Kerkhof PL, Vermeer F et al (1988) Relation between infarct size and left ventricular performance assessed in patients with first acute myocardial infarction randomized to intracoronary thrombolytic therapy or to conventional treatment. Am J Cardiol 61:1-7

45. van der Hoeven BL, Pires NM, Warda HM et al (2005) Drug-eluting stents: results, promises and problems. Int J Cardiol 99:9-17
46. Ertaş G, van Beusekom HM, van der Giessen WJ (2009) Late stent thrombosis, endothelialisation and drug-eluting stents. Neth Heart J 17:177-180

47. Tops LF, Bax JJ, Zeppenfeld K et al (2005) Fusion of multislice computed tomography imaging with threedimensional electroanatomic mapping to guide radiofrequency catheter ablation procedures. Heart Rhythm 2: 1076-1081

48. Marques KM, Westerhof N (2008) Characteristics of the flow velocity-pressure gradient relation in the assessment of stenoses: an in vitro study. Neth Heart J 16:156-162

49. Sirineni GK, Raggi P, Shaw LJ, Stillman AE (2008) Calculation of coronary age using calcium scores in multiple ethnicities. Int J Cardiovasc Imaging 24:107-111

50. van der Wall EE (2009) CT angiography, underuse, overuse, or appropriate use? Neth Heart J 17:223

51. van Mieghem CA, de Feyter PJ (2009) Combining noninvasive anatomical imaging with invasive functional information: an unconventional but appropriate hybrid approach. Neth Heart J 17:292-294

52. Knaapen P, de Haan S, Hoekstra OS et al (2010) Cardiac PET-CT: advanced hybrid imaging for the detection of coronary artery disease. Neth Heart J 18:90-98

53. Rodríguez-Granillo GA, Rosales MA, Degrossi E, Rodriguez AE (2009, Nov 12) Signal density of left ventricular myocardial segments and impact of beam hardening artifact: implications for myocardial perfusion assessment by multidetector CT coronary angiography. Int $\mathrm{J}$ Cardiovasc Imaging [Epub ahead of print]

54. Pazhenkottil AP, Husmann L, Buechel RR et al. (2010, Feb 4) Validation of a new contrast material protocol adapted to body surface area for optimized low-dose CT coronary angiography with prospective ECG-triggering. Int J Cardiovasc Imaging [Epub ahead of print]

55. Tatsugami F, Husmann L, Herzog BA et al (2009) Evaluation of a body mass index-adapted protocol for low-dose 64-MDCT coronary angiography with prospective ECG triggering. AJR Am J Roentgenol 192:635-638

56. Herzog BA, Husmann L, Valenta I et al (2009) Determinants of vessel contrast in BMI-adapted low dose CT coronary angiography with prospective ECG-triggering. Int J Cardiovasc Imaging 25:625-630

57. Husmann L, Tatsugami F, Aepli U et al (2009) Prevalence of noncardiac findings on low dose 64-slice computed tomography used for attenuation correction in myocardial perfusion imaging with SPECT. Int J Cardiovasc Imaging 25:859-865

58. Husmann L, Herzog BA, Burkhard N et al (2009) Low-dose coronary $\mathrm{CT}$ angiography with prospective ECG triggering: validation of a contrast material protocol adapted to body mass index. AJR Am J Roentgenol 193:802-806 